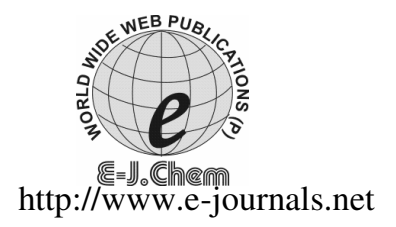

ISSN: 0973-4945; CODEN ECJHAO
E-Journal of Chemistry
2011, 8(2), 603-608

\title{
Stacking Structure of Quinolinium Hydrogensquarate
}

\author{
M. M. BELOMBE ${ }^{*}$, J. NENWA ${ }^{\S}$ and F. EMMERLING ${ }^{\#}$ \\ ${ }^{*}$ Department of Inorganic Chemistry, Faculty of Science \\ University of Yaounde I, POB 812, Yaounde, Cameroon \\ \#BAM Federal Institute for Materials Research and Testing, \\ Richard-Willstätter-Str.,11 D-12489 Berlin-Adlershof, Germany \\ belombe2000@yahoo.fr
}

Received 17 April 2010; Accepted 10 June 2010

\begin{abstract}
A new proton-transfer organic salt, quinolinium hydrogensquarate $\left(\mathrm{C}_{13} \mathrm{H}_{9} \mathrm{NO}_{4}\right)$, has been synthesized and fully characterized by single crystal $\mathrm{x}$-ray diffraction. The salt crystallizes in the monoclinic space group $P 2_{1} / \mathrm{n}$ with the parameters: $a=3.8290(12) \AA, b=20.960(6) \AA, c=13.802(4) \AA$, $\beta=95.452(5)^{\circ}, V=1102.7(6) \AA^{3}, Z=4$ formula units. The structure consists of uncommon supramolecular neutral dimers which pile up parallel to [100] forming infinite sheets. These centrosymmetric dimers are held together by lateral hydrogen-bonds whereby two neighboring coplanar hydrogensquarate anions act as a bridge between two terminal quinolinium cations and C-H...O bridgings interlink next neighboring sheets. The bulk structure of this salt is consolidated by weak $\pi-\pi$ interactions within the sheets which are neatly ordered side-by-side relative to one another.
\end{abstract}

Keywords: Quinolinium squarate, Supramolecular dimer, Crystal structure, Proton-transfer salt.

\section{Introduction}

The strategy of self-assembly, which makes use of in-built molecular capabilities to direct stereoselectively the association of chemical building blocks of comparable dimensions, has been widely applied in current research to design and develop new materials that are needed to foster emerging technologies ${ }^{1-3}$. In this respect, the vanguard field of onedimensional metals typified by the TTF-TCNQ salt ${ }^{4}$ (TTF is tetrathiafulvalene; TCNQ is 
Tetracyano- $p$-quinodimethane) and related organic conductors ${ }^{5}$ has been at the focus of interest in contemporary research and development.

Our current research program aims to fabricate Heisenberg-type magnetic materials suitable for systematic studies of long-range magnetic interactions as a function of on-site spin densities. Recently, indeed, we isolated quinolinium trans-diaquabis(oxalato) chromate(III) ${ }^{6}$, an organic-inorganic hybrid salt that crystallizes in an interesting structure formed by segregated infinite stacks of diamagnetic organic cations and paramagnetic inorganic complex anions, with a regular spacing of 6.635(1) A between next neighboring $\mathrm{Cr}^{\mathrm{III}}$ centers. Herein, we describe the title compound as a useful precursor for the provision of the flat ions needed in forthcoming metathetic syntheses.

\section{Experimental}

The synthetic procedure was initially targeted at a salt involving the dinegative squarate(2-) ion; we rather obtained, however, the salt with the mononegative hydrogensquarate(1-) ion. Thus, squaric acid, i.e. 3,4-dihydroxy-3-cyclobutene-1,2-dione (1.15 g, $10 \mathrm{mmol}$, Aldrich $99 \%$ ), dissolved in $60{ }^{\circ} \mathrm{C}$ warm $\mathrm{H}_{2} \mathrm{O}(50 \mathrm{~mL})$ was treated with a solution of quinoline $(2.60 \mathrm{~g}$, $20 \mathrm{mmol}$, Riedel-de Haën, PROSYNTH) in dioxane (20 mL, PROBUS, chem. pure) and stirred over $3 \mathrm{~h}$. After filtration, the solution was concentrated slowly at $c a .40{ }^{\circ} \mathrm{C}$ in the hood to a volume of about $10 \mathrm{~mL}$. The fibrous solid that had formed was separated by filtration, washed twice with dioxane $(10 \mathrm{~mL})$, dried first in air, then at $100{ }^{\circ} \mathrm{C}$ in an oven, yielding $2.42 \mathrm{~g}(96 \%)$ of whitish material. Following recrystallization from $\mathrm{H}_{2} \mathrm{O}$, elongated crystals suitable for $\mathrm{x}$-ray diffraction were obtained, melting at $241.9-242.2{ }^{\circ} \mathrm{C}$ with decomposition. Anal. Calc. for $\mathrm{C}_{13} \mathrm{H}_{9} \mathrm{NO}_{4}: \mathrm{C}, 64.20 ; \mathrm{H}, 3.70 ; \mathrm{N}, 5.76 \%$. Found: $\mathrm{C}, 64.13 ; \mathrm{H}$, 3.78; N, 5.72\% (CHN analysis performed by using a Thermo FlashEA 1112 series Elemental Analyzer).

\section{Structural determination}

Crystal data for the title compound were collected on a Bruker-AXS SMART APEX CCD diffractometer at 293(2) $\mathrm{K}$ using Mo $K \alpha$ graphite monochromated radiation $(\lambda=0.71073 \AA$ ) and an $\omega-2 \theta$ scan mode $\left(1.77^{\circ}<\theta<23.35^{\circ}\right)$. Data reduction was performed with the use of the Bruker AXS SAINT ${ }^{7}$ and $\mathrm{SADABS}^{8}$ packages. The structure was solved by direct methods and refined by full-matrix least-squares calculations using SHELXS-97 ${ }^{9}$, All nonhydrogen atoms were refined anisotropically on $F^{2}$. Hydrogen atoms were calculated isotropically at their fixed positions and allowed to ride on their respective parent atoms. The contributions of these hydrogen atoms were included in structure calculations. Atomic scattering factors and anomalous dispersion corrections were taken from International Tables for x-ray Crystallography ${ }^{10}$. Crystal data and structure refinement for the title compound are summarized in Table 1.

\section{Results and Discussion}

An ORTEP ${ }^{11}$ plot of the title compound is displayed in Figure 1. This purely organic protontransfer salt is readily soluble in water and it is considered a convenient source for the desirable planar ionic constituents. Selected bond lengths and angles are listed in Table 2. They differ slightly from the values reported for the quinolinium cation ${ }^{3}$ and the dinegative squarate anion $^{12,13}$, respectively. 
Table 1. Crystal data and structure refinement for the title compound

\begin{tabular}{ll}
\hline CCDC N $^{\circ}$ & $\mathrm{CCDC}^{\circ} 698315$ \\
\hline Empirical formula & $\mathrm{C}_{13} \mathrm{H}_{9} \mathrm{NO}_{4}$ \\
Formula weight & 243.21 \\
Temperature, $(\mathrm{K})$ & $293(2)$ \\
Wavelength $(\AA)$ & 0.71073 \\
Crystal system & monoclinic \\
Space group & $P 2_{1} / \mathrm{n}$ \\
Unit cell dimensions & \\
$a(\AA)$ & $3.8335(4)$ \\
$b(\AA)$ & $20.954(2)$ \\
$c\left(^{\AA}\right)$ & $13.827(2)$ \\
$\beta\left(^{\circ}\right)$ & $95.223(6)$ \\
Volume $\left(\AA^{3}\right)$ & $1106.1(2)$ \\
$Z$ & 4 \\
Density (calculated, gcm & \\
Absorption coefficient, $\mathrm{mm}^{-1}$ & 1.460 \\
$F(000)$ & 0.110 \\
Crystal size (mm)/Prismatic & 504 \\
$\theta$ range for data collection $\left({ }^{\circ}\right)$ & $0.2 \times 0.13 \times 0.1$ \\
Limiting indices & $1.77-28.35$ \\
& $-5 \leq h \leq 5$ \\
& $-27 \leq k \leq 27$ \\
Reflections collected & $-18 \leq l \leq 18$ \\
Independent reflections & 23677 \\
Refinement method & $2741[R($ int $)=0.1194]$ \\
Data / restraints / parameters & Full-matrix least-squares on $F^{2}$ \\
Goodness-of-fit on $F$ & $2741 / 0 / 164$ \\
Final $R$ indices $[I>2 \sigma(I)]$ & 1.007 \\
$R$ indices (all data) & $R 1=0.0376, \mathrm{w} R 2=0.0698$ \\
Largest diff. peak and hole $\left(\mathrm{e} \AA^{-3}\right)$ & $R 1=0.0459, \mathrm{w} R 2=0.0841$ \\
Extinction coefficient & 0.116 and -0.15 \\
Completeness to theta $=28.35^{\circ}, \%$ & $9.022(3)$ \\
\hline & 99.5 \\
\hline &
\end{tabular}
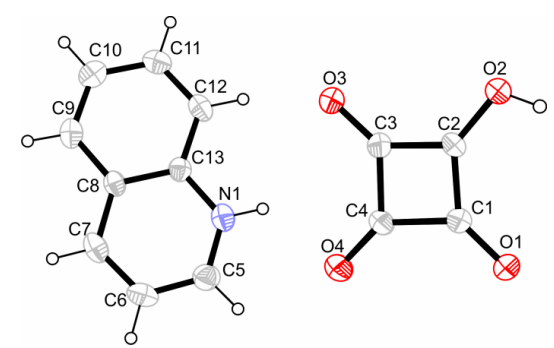

Figure 1. The structure of quinolinium hydrogensquarate, HqnHsq, with displacement ellipsoids drawn at the $30 \%$ probability level 
Table 2. Selected bond lengths $(\AA)$ and bond angles $\left(^{\circ}\right)$ for the title compound

\begin{tabular}{|c|c|c|c|}
\hline Atoms & Bond lengths [̊] & Atoms & Bond lengths $[\AA]$ \\
\hline N1-C5 & $1.368(2)$ & $\mathrm{C} 3-\mathrm{C} 4$ & $1.429(2)$ \\
\hline $\mathrm{N} 1-\mathrm{C} 9$ & $1.322(2)$ & C5-C6 & $1.410(2)$ \\
\hline $\mathrm{O} 1-\mathrm{C} 1$ & $1.229(2)$ & C6-C7 & $1.411(2)$ \\
\hline $\mathrm{O} 2-\mathrm{C} 2$ & $1.256(2)$ & $\mathrm{C} 7-\mathrm{C} 8$ & $1.367(2)$ \\
\hline $\mathrm{O} 3-\mathrm{C} 3$ & $1.315(2)$ & C5-C13 & $1.401(2)$ \\
\hline $\mathrm{O} 4-\mathrm{C} 4$ & $1.248(2)$ & C8-C9 & $1.385(2)$ \\
\hline $\mathrm{C} 1-\mathrm{C} 2$ & $1.477(2)$ & C6-C10 & $1.410(2)$ \\
\hline $\mathrm{C} 1-\mathrm{C} 4$ & $1.488(2)$ & $\mathrm{C} 10-\mathrm{C} 11$ & $1.358(2)$ \\
\hline \multirow[t]{2}{*}{$\mathrm{C} 2-\mathrm{C} 3$} & $1.423(2)$ & $\mathrm{C} 11-\mathrm{C} 12$ & $1.400(2)$ \\
\hline & & $\mathrm{C} 12-\mathrm{C} 13$ & $1.366(2)$ \\
\hline Atoms & Bond angle $\left[{ }^{\circ}\right]$ & Atoms & Bond angle $\left[{ }^{\circ}\right]$ \\
\hline C9-N1-C5 & $122.95(14)$ & $\mathrm{C} 2-\mathrm{C} 1-\mathrm{C} 4$ & $88.74(12)$ \\
\hline $\mathrm{N} 1 \mathrm{C} 5-\mathrm{C} 13$ & $120.40(15)$ & $\mathrm{O} 1-\mathrm{C} 1-\mathrm{C} 3$ & $179.34(14)$ \\
\hline N1-C5-C6 & $118.52(15)$ & $\mathrm{C} 2-\mathrm{C} 1-\mathrm{C} 3$ & $44.27(9)$ \\
\hline C13-C5-C6 & $121.08(16)$ & $\mathrm{C} 4-\mathrm{C} 1-\mathrm{C} 3$ & $44.48(9)$ \\
\hline C10-C6-C5 & $118.10(15)$ & $\mathrm{O} 2-\mathrm{C} 2-\mathrm{C} 3$ & $136.31(15)$ \\
\hline C10-C6-C7 & $123.76(15)$ & $\mathrm{O} 2-\mathrm{C} 2-\mathrm{C} 1$ & $134.36(14)$ \\
\hline $\mathrm{C} 5-\mathrm{C} 6-\mathrm{C} 7$ & $118.14(16)$ & $\mathrm{C} 3-\mathrm{C} 2-\mathrm{C} 1$ & $89.34(13)$ \\
\hline C8-C7-C6 & $120.39(16)$ & $\mathrm{O} 3-\mathrm{C} 3-\mathrm{C} 2$ & $130.49(15)$ \\
\hline C7-C8-C9 & $119.53(17)$ & $\mathrm{O} 3-\mathrm{C} 3-\mathrm{C} 4$ & $136.24(15)$ \\
\hline N1-C9-C8 & $120.44(17)$ & $\mathrm{C} 2-\mathrm{C} 3-\mathrm{C} 4$ & $93.26(13)$ \\
\hline $\mathrm{C} 11-\mathrm{C} 10-\mathrm{C} 6$ & $120.34(16)$ & $\mathrm{O} 3-\mathrm{C} 3-\mathrm{C} 1$ & $176.84(14)$ \\
\hline C10-C11-C12 & $120.72(17)$ & $\mathrm{C} 2-\mathrm{C} 3-\mathrm{C} 1$ & $46.40(9)$ \\
\hline C13-C12-C11 & $121.02(16)$ & $\mathrm{C} 4-\mathrm{C} 3-\mathrm{C} 1$ & $46.86(9)$ \\
\hline C12-C13-C5 & $118.73(16)$ & $\mathrm{O} 4-\mathrm{C} 4-\mathrm{C} 3$ & $137.76(15)$ \\
\hline $\mathrm{O}(1)-\mathrm{C}(1)-\mathrm{C}(2)$ & $135.09(15)$ & $\mathrm{O} 4-\mathrm{C} 4-\mathrm{C} 1$ & $133.57(15)$ \\
\hline $\mathrm{O}(1)-\mathrm{C}(1)-\mathrm{C}(4)$ & $136.17(15)$ & $\mathrm{C} 3-\mathrm{C} 4-\mathrm{C} 1$ & $88.66(13)$ \\
\hline
\end{tabular}

As shown in Figure 2, dimerized formula units are the actual building blocks that generate the lattice network of the title compound. These dimers arise as the result of efficient side-by-side hydrogen bonds (Table 3 ) interlinking the ions into faintly corrugated neutral supramolecular motifs, with a dihedral angle of $23.97^{\circ}$ between the central core of two coplanar hydrogensquarate anions and the two terminal quinolinium cations on both ends. The dimerization process, therefore, may be understood as occurring in two consecutive stages. First the two hydrogensquarate ions are dimerized, forming a dinegative coplanar motif in such a way that the $\mathrm{O}-\mathrm{H}$ group of one monomer undergoes a hydrogenbond with the deprotonated $\mathrm{O}$ atom of the other monomer and vice-versa. Second the $\mathrm{N}-\mathrm{H}$ group of each quinolinium cation is hydrogen-bonded to one carbonyle $\mathrm{O}$ atom of each hydrogensquarate anion. These neutral dimers then stack on top of each other in nearly eclipsed configuration along the $a$ axis with a regular centroid inter-dimer spacing of 3.829 $\AA$, thus forming infinite sheets that run parallel to [100]. From Figure 2, one easily recognizes that the main planes of these sheets are oriented along two crystallographic directions which enclose a dihedral angle of approximately $60^{\circ}$. The intra-sheet spacing of $3.829 \AA$ ( $a$ axis) between nearest dimers may be interpreted as resulting from weak $\pi-\pi$ interactions between next neighboring dimers. It is worth noting that in this crystal structure, $\mathrm{O}-\mathrm{H} \ldots \mathrm{O}$ bonding is effective only within and not between the dimeric motifs. The bulk 
crystal structure, however, is stabilized by C-H...O bridgings between the sheets and by the judicious space filling of these infinite sheets which are neatly arranged side-by-side in a manner reminiscent of the relative sheet ordering of the anions in the structure of the $\left[\mathrm{NBu}_{4}\right]\left[\mathrm{Ni}(\mathrm{bdt})_{2}\right]$ salt $^{14}$, bdt ${ }^{2-}$ being the dianion of benzene-1,2-dithiol.

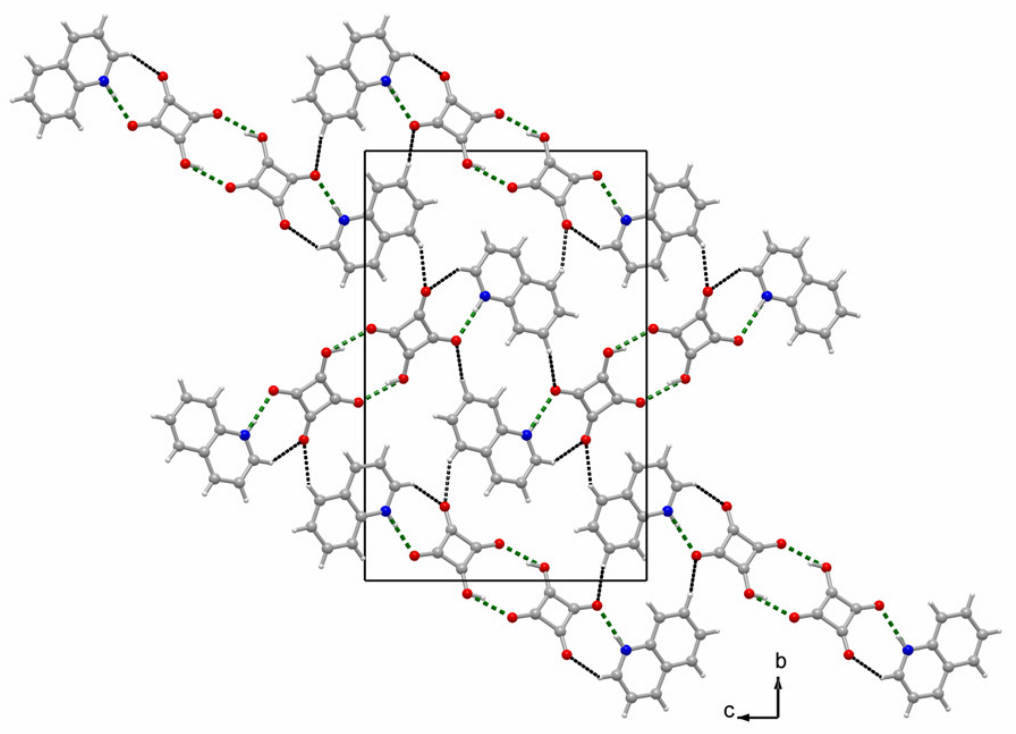

Figure 2. The unit cell packing diagram of the title compound projected along the $a$ axis, showing dimerization of the HqnHsq formula units via lateral $\mathrm{N}-\mathrm{H} . . . \mathrm{O}$ and $\mathrm{C}-\mathrm{H}$...O bonds (dotted lines), closely similar to the side-by-side sheets arrangement of [ $\left.\mathrm{Ni}(\mathrm{bdt})_{2}\right]^{-}$ions in the structure of $\left[\mathrm{NBu}_{4}\right]\left[\mathrm{Ni}(\mathrm{bdt})_{2}\right]^{14}\left(\mathrm{bdt}^{2-}=\right.$ benzene-1,2-dithiolate $)$

Table 3. Intermolecular interactions $\left(\AA,^{\circ}\right)$ for the title compound

\begin{tabular}{ccccc}
\hline $\mathrm{D}-\mathrm{H} \ldots$ & $\mathrm{A}$ & $\mathrm{H} \ldots \mathrm{A}[\AA]$ & $\mathrm{D} \ldots \mathrm{A}[\AA]$ & $\angle \mathrm{D}-\mathrm{H} \ldots \mathrm{A}\left[{ }^{\circ}\right]$ \\
\hline $\mathrm{N} 1-\mathrm{H} 1$ & $\mathrm{O} 2^{\mathrm{I}}$ & 1.81 & $2.669(2)$ & 171 \\
$\mathrm{O} 3-\mathrm{H} 3$ & $\mathrm{O}^{\mathrm{II}}$ & 1.52 & $2.518(2)$ & 154 \\
$\mathrm{C} 9-\mathrm{H} 9$ & $\mathrm{O}^{\mathrm{I}}$ & 2.52 & $3.305(2)$ & 142 \\
$\mathrm{C} 10-\mathrm{H} 10$ & $\mathrm{O}^{\mathrm{III}}$ & 2.44 & $3.285(2)$ & 153 \\
$\mathrm{C} 12-\mathrm{H} 12$ & $\mathrm{O}^{\mathrm{IV}}$ & 2.57 & $3.372(2)$ & 145 \\
\hline
\end{tabular}

\section{Conclusion}

Quinolinium hydrogensquarate, $\mathrm{C}_{13} \mathrm{H}_{9} \mathrm{NO}_{4}$, is a novel proton-transfer organic salt which crystallizes in the monoclinic space group $P 2_{1} / \mathrm{n}$, with the flat ions hydrogen-bonded into centro-symmetric supramolecular dimers; these neutral dimers pile up on top of each other to form sheets running parallel to [100].

\section{Supplementary material}

All crystallographic data for this paper were deposited with the Cambridge Crystallographic Data Centre (CCDC-698315). The data can be obtained free of charge at www.ccdc.cam.ac.uk/conts/retrieving.html [or from Cambridge Crystallographic Data Centre (CCDC), 12 Union Road, Cambridge CB2 IEZ, UK; fax: +44 (0) 1223-336033; e-mail: deposit@ccdc.cam.ac.uk]. 


\section{Acknowledgment}

The authors thank Prof. Ahmed Semmoud (University of Lille I, France) for a donation of squaric acid and François E. Meva (T U Chemnitz, Germany) for his help with the elemental analysis.

\section{References}

1. Moulton B and Zaworotko M J, Chem Rev., 2001, 101, 1629-1658.

2. Rao C N R and Nath H, Dalton Trans., 2003, 1-24.

3. Brus L, Yang P, Peng X, Norris D, Dai H and Chidsey C, Prog Solid State Chem., 2002, 30, 1-101.

4. Heeger A J, in Highly Conducting One-Dimensional Solids, Eds. Devreese J T, Evrard R P and van Doren V E, Plenum Press, New York, 1979, pp. 69-140 and references therein.

5. Kobayashi H, Marumo F and Saito Y, Acta Cryst., 1971, B27, 373-378.

6. Bélombé M M, Nenwa J and Emmerling F, Zkristallogr NCS., 2009, 224, 239-240.

7. SAINT: Area-Detector Integration Software. Version 6.01, Siemens Industrial Automation, Inc.: Madison, WI, 1999.

8. Sheldrick G M, SADABS, Program for Scaling and Correction of Area-Detector Data, University of Göttingen, Germany, 1997.

9. Sheldrick G M, SHELX97 [Includes SHELXS97, SHELXL97]: Program for Crystal Structure Analysis (Release 97-2), University of Göttingen, Germany, 1997.

10. Wilson A J, International Tables for X-ray Crystallography; Kynoch Press: Birmingham, England (Present distributor: Kluwer Academic Publisher: Dordrecht), 1992, Vol. C, Tables 6.1.1.4 (pp. 500-502) and 4.2.6.8 (pp. 219-222), respectively.

11. ORTEP3 for Windows: Farrugia L J, J Appl Crystallogr., 1997, 30, 565.

12. Endres H and Schendzielorz M, Acta Cryst., 1983, C39, 1528-1530.

13. Massoud S S, Mautner F A, Vincente R and Dickens J S, Inorg Chim Acta,, 2008, 361, 299-308.

14. Robertson N, Parsons S, Awaga K and Fujita W, Cryst Eng Comm., 2000, 2, 121-124. 


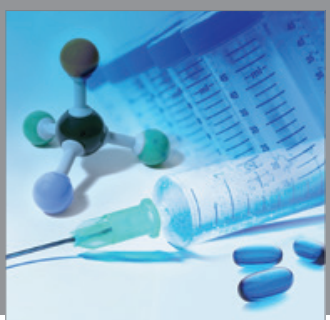

International Journal of

Medicinal Chemistry

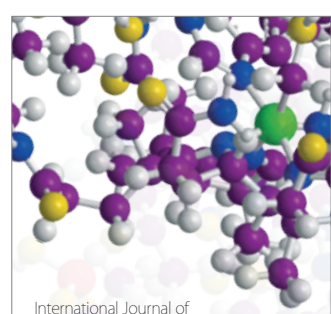

Carbohydrate Chemistry

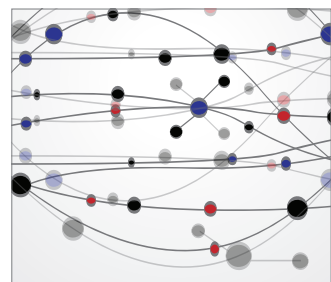

The Scientific World Journal
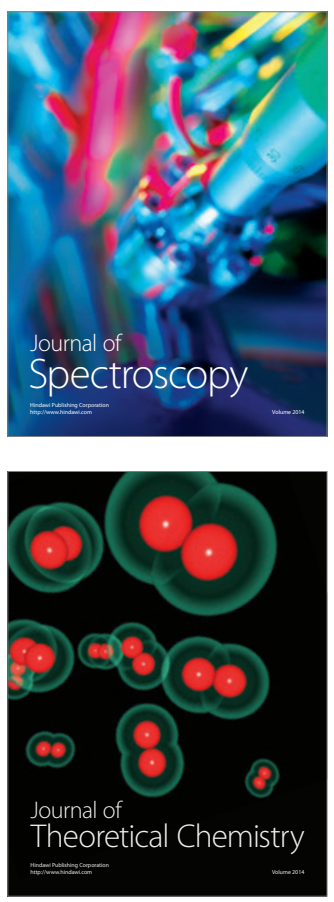
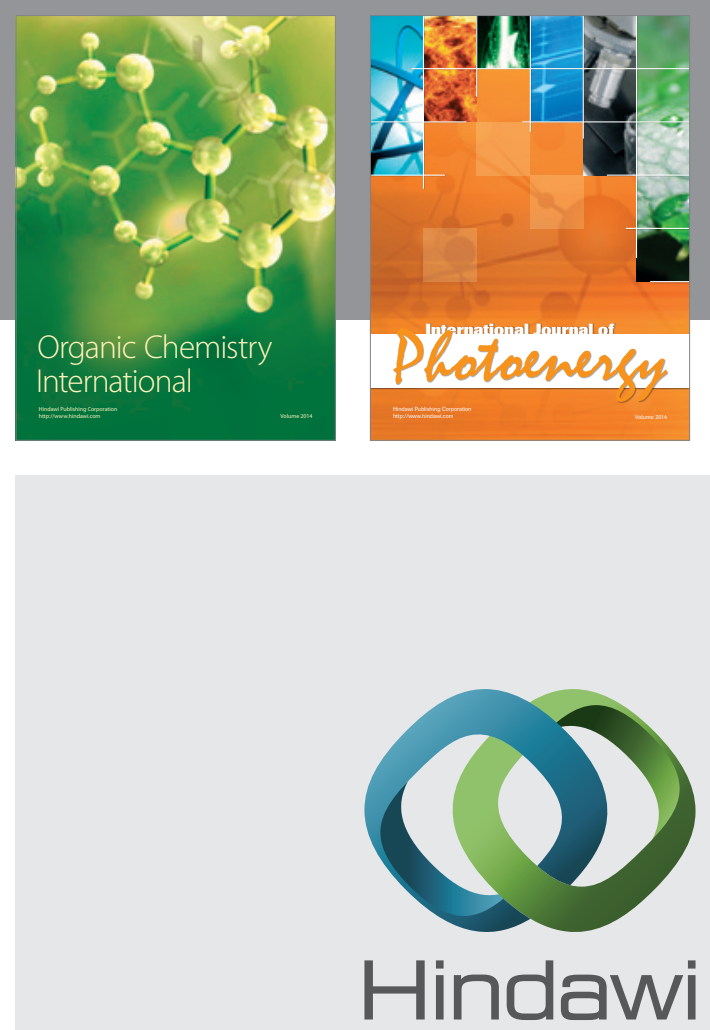

Submit your manuscripts at

http://www.hindawi.com
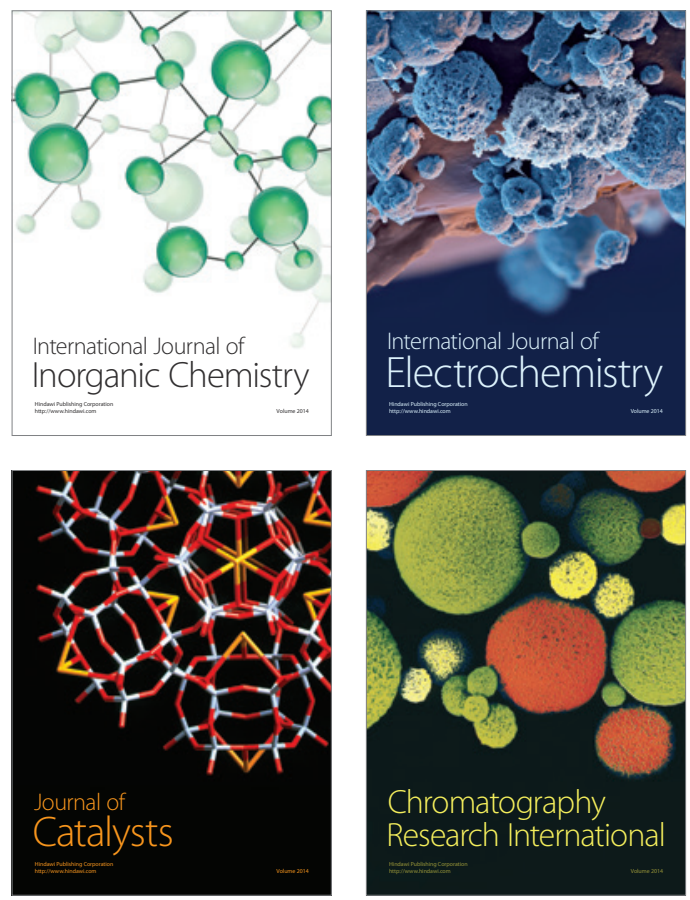
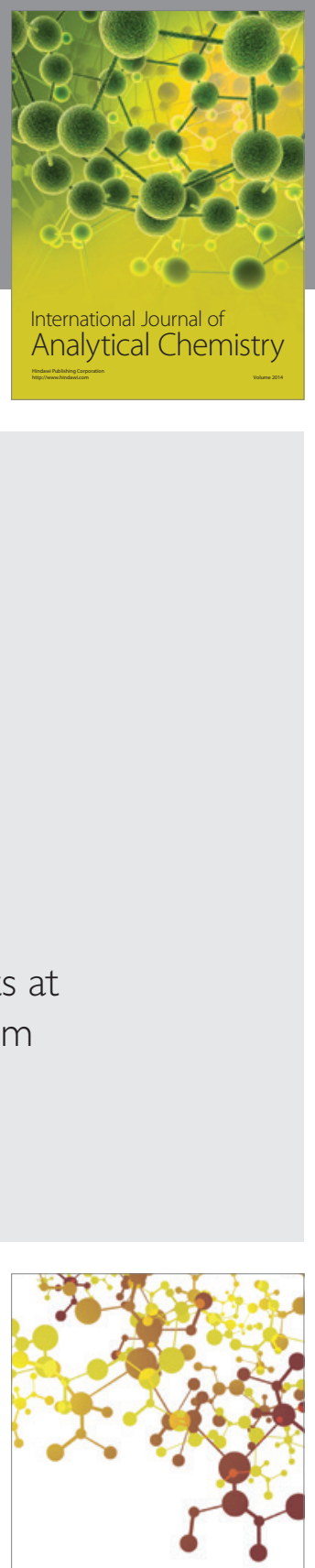

Journal of

Applied Chemistry
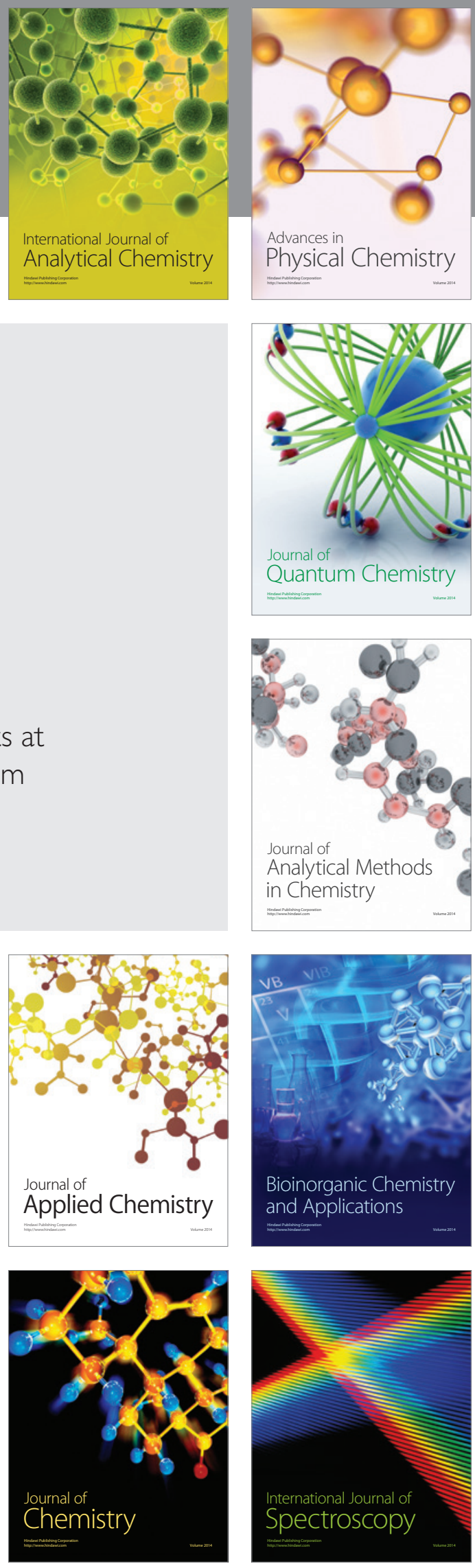